\title{
Implementasi Metode Dempster Shafer pada Sistem Pakar Diagnosis Penyakit Ayam
}

\author{
(Implementation of Dempster Shafer Method on Expert System of Diagnosing \\ Chicken Disease)
}

\author{
Salsabila Putri Rajani Said*, I Gede Pasek Suta Wijaya, Fitri Bimantoro \\ Program Studi Teknik Informatika, Universitas Mataram \\ J1. Majapahit 62, Mataram, Lombok NTB, INDONESIA \\ Email: salsarajani21@gmail.com, [gpsutawijaya,bimo]@unram.ac.id
}

\section{*penulis korespondensi}

\begin{abstract}
Chicken is one type of poultry that has many benefits, so the chicken can be an option for livestock. This research was conducted to create an expert system that helps provide information to farmers about poultry diseases, especially broilers. This expert system is built on the Android platform and uses the Dempster Shafer calculation method to get the diagnosis of chicken disease. The data used in this study consisted of 38 symptoms and 10 diseases data which were limited to diseases caused by bacteria and viruses. Each symptom has the value of belief given by 3 veterinarians. This study used four types of testing in the form of black-box, questionnaire, theoretical, and accuracy testing. The results of the accuracy testing of the 30 cases given are $92.22 \%$ and the system accuracy is $\mathbf{9 3 . 3 3 \%}$ if the system diagnosis results are assumed to be valid because it is a subsection of expert diagnosis. For questionnaire testing using the MOS, parameters obtained 4.58 results from a scale of 5 , as well as theoretical calculation tests that get the same calculation results between the results of expert diagnoses and system diagnoses. Based on the test results, the system built is good and appropriate.
\end{abstract}

Key words: Expert System, Chicken Disease, Dempster Shafer, Android, Broiler.

\section{PENDAhULUAN}

Ayam merupakan salah satu jenis unggas yang dapat dimanfaatkan daging, telur, serta bulunya, sehingga di Indonesia ayam merupakan salah satu pilihan untuk dijadikan hewan ternak[1]. Menurut Badan Pusat Statistik pada tahun 2018 jumlah populasi ayam di Indonesia yaitu sebanyak 1.891.434.612 ekor untuk ayam ras pedaging[2]. Jumlah populasi untuk ayam petelur di Indonesia yaitu sebanyak 181.752.456 ekor[3]. Selain ayam pedaging dan petelur terdapat jumlah populasi untuk ayam buras yaitu sebanyak 310.959.951 ekor[4]. Ayam pedaging merupakan jenis ayam dengan populasi terbanyak, begitu pula pada Kabupaten Lombok Timur. Berdasarkan data survei Dinas Perternakan dan Kesehatan Hewan Kabupaten Lombok Timur Tahun 2017, populasi ayam pedaging mencapai total 2.945.674 ekor dari 20 kecamatan yang ada di Lombok Timur[5].

Ayam pedaging atau yang lebih dikenal sebagai ayam broiler merupakan jenis ayam yang memiliki produktivitas tinggi karena berasal hasil persilangan beberapa ras unggulan ayam. Pemeliharan ayam pedaging terbilang singkat, dimana pada umur $4-5$ minggu ayam pedaging atau ayam broiler sudah dapat dipanen. Bobot badan ayam broiler yang sudah siap dipanen berkisar antara 1,2 - 1,9 kg/ekor[6]. Dengan pemeliharaan yang relatif lebih singkat, produksi ayam dalam menghasilkan daging memiliki efek yang rentan terhadap penyakit yang mampu menyerang kesehatannya. Kurangnya perhatian dalam pemberian nutrisi bahan pakan yang diberikan serta faktor lain seperti faktor cuaca dan kondisi sanitasi kandang yang tidak terkelola dengan baik oleh para peternak menjadi penyebab permasalahan timbulnya penyakit pada ayam tersebut. Pada umumnya penyakit-penyakit yang sering menjangkit ayam broiler yaitu seperti Cronic Respiratory Disease (CRD), Corryza, Newcastle Disease (ND) atau tetelo, Infectious Bursal Disease (IBD) atau Gumboro, Koksidiosis (Berak Darah), dan flu burung (Avian Influenza) [7].

Rendahnya pengetahuan menganai penyebab, gejala serta penanganan yang tepat oleh peternak dapat berakibat kematian pada ayam yang akhirnya peternak mengalami kerugian apabila persentase kematian cukup tinggi. Jumlah PUSKESWAN pada Kabupaten Lombok Timur yaitu sebanyak 17 PUSKESWAN dari 21 kecamatan dan jumlah dokter hewan pada Kabupaten Lombok Timur yaitu sebanyak 23 dokter hewan[8]. Dari data yang ada jumlah PUSKESWAN dan tenaga dokter hewan masih kurang sebanyak 4 PUSKESWAN dan 4 dokter hewan. Terbatasnya jumlah dokter hewan saat ini menyebabkan penanganan terhadap ternak hewan menjadi lambat sehingga para peternak akhirnya melakukan penanganan sendiri dengan cara tradiosional berdasarkan pengalaman yang mereka miliki.

Sistem pakar merupakan sistem yang meniru kemampuan atau pengetahuan seorang pakar ke komputer, pengetahuan yang ditiru ini dirancang pada komputer dengan memodelkan kemampuan agar dapat 
menyelesaikan masalah seperti layaknya seorang pakar[9]. Dalam sistem pakar terdapat beberapa metode seperti Bayesian Network, Dempster Shafer dan Certainty Factor untuk perhitungan ketidak konsistenan. Pada beberapa penelitian terdahulu yang membandingkan pengimplementasian antara metode Dempster Shafer dan Certainty Factor didapatkan bahwa metode Dempster Shafer mendapatkan nilai akurasi yang lebih tinggi dibandingkan dengan metode Certainty Factor[10][11] dan juga pada penelitian yang membandingkan metode Dempster Shafer dengan metode Bayesian Network[12].

Selain tingkat keakurasian yang lebih tinggi metode Dempster Shafer adalah metode yang menerapkan penalaran non monotonis, sehingga diharapkan mampu mengatasi ketidakkonsistenan pada gejala penyakit yang diderita. Penalaran non monotonis merupakan penalaran yang terjadi akibat adanya penambahan fakta baru yang akan merubah aturan yang ada. Dengan penggunaan metode ini dapat diharapkan meminimalisirkan ketidakpastian sehingga menghasilkan diagnosis yang valid [13].

Berdasarkan dari uraian di atas dan dengan perkembangan teknologi mengenai sistem pakar, penulis akan membangun suatu sistem untuk mengetahui penyakit yang dapat menyerang hewan ternak ayam dengan mendiagnosis dari gejala yang dialami oleh ayam menggunakan metode Dempster Shafer. Sistem ini akan dibangun berbasis mobile dengan platform Android dikarenakan platform Android merupakan platform terbuka bagi pengembang untuk menciptakan berbagai aplikasi sehingga dapat dimanfaatkan dalam proses implementasi sistem pakar dan juga pengguna platform Android telah mencapai $90 \%$ pada pasar smartphone di Indonesia dan $75 \%$ pengguna di dunia[14].

\section{TINJAUAN PUSTAKA DAN DASAR TEORI}

\section{A. Tinjauan Pustaka}

Penelitian tentang sistem pakar untuk diagnosis penyakit pada ayam dengan metode fuzzy tsukamoto digunakan untuk mendiagnosis 6 jenis penyakit yang diderita ayam[1]. Penelitian menggunakan 20 data yang didapatkan dari seorang pakar. Dari hasil yang diperoleh sistem ini memiliki tingkat keakurasian sebesar $87,25 \%$. Namun, pada sistem ini belum dapat dilakukan manipulasi data kasus yang ada yaitu berupa penambahan data gejala dan penyakit.

Penelitian tentang sistem pakar untuk mendiagnosis penyakit pada ayam dengan metode Certainty Factor menggunakan data sebanyak 19 jenis penyakit[15]. Pada penelitian ini digunakan metode forward chaining sebagai mesin inferensinya. Dalam pengujian diagnosis didapatkan tingkat kesesuaiannya telah mencapai 99\%. Namun, pada penelitian ini penyakit yang didiagnosis hanya berbatas pada penyakit yang disebabkan oleh bakteri saja.

Penelitian tentang penerapan metode Dempster Shafer pada sistem pakar diagnosis penyakit ayam broiler menggunakan data sebanyak 9 jenis penyakit yang disebabkan bakteri dan virus[9]. Namun pada penelitian ini, sistem hanya akan menghitung sampai dengan nilai densitas dari kesimpulan diagnosis penyakit yang di dapatkan dan tidak mengetahui sejauh mana performa dari sistem tersebut.

Penelitian tentang sistem diagnosis penyakit bakteri ayam ternak menggunakan metode Dempster Shafer menggunakan 7 data penyakit. Nilai rata-rata pengujian akurasi pada penelitian didapatkan sebesar 99,1584314\% dengan error rate $0,8415686 \%$. [16].

Penelitian tentang sistem pakar diagnosis penyakit ayam broiler dengan metode Dempster Shafer menggunakan 16 data penyakit. Pada penelitian ini tidak dilakukan perhitungan untuk pengujian akurasi sistem yang dibangun, serta sistem belum dapat menampilkan diagnosis apabila dilakukan penambahan atau perubahan aturan yang ada[17].

Penelitian tentang sistem pakar diagnosis penyakit sapi menggunakan metode Dempster Shafer menggunakan 21 data penyakit. Pada sistem ini nilai rata-rata keakurasian yang didapatkan yaitu cukup tinggi sebasar 87,2\% dari 10 data kasus yang digunakan[13].

Penelitian tentang sistem pakar untuk mendiagnosis gangguan mental anak menggunakan metode Dempster Shafer mendiagnosis 8 penyakit gangguan mental pada anak usia 4-17 tahun. Dalam penelitian ini sistem mendapatkan suatu nilai kepercayaan dari gejala berdasarkan jawaban dari 3 orang pakar. Sistem ini memiliki tingkat akurasi sebesar $95 \%$ dari 40 kasus rekam medis yang digunakan[18].

Penelitian tentang metode Dempster Shafer pada sistem pakar untuk diagnosis jenis-jenis penyakit diabetes melitus dimana terdapat 7 data jenis penyakit. Pada penelitian ini sistem menggunakan data uji sejumlah 30 data analisa pakar dan mendapatkan nilai akurasi sebesar 96,67\% bahwa sistem dapat berfungsi dengan baik dan sesuai dengan diagnosis pakar[19].

Penelitian tentang analisis perbandingan sistem pakar dengan metode Certainty Factor dan metode Dempster Shafer pada penyakit kelinci menggunakan 9 jenis penyakit yang umum terjadi pada kelinci serta 20 data kasus penyakit kelinci yang dijadikan sebagai bahan uji. Pada pengujian dengan metode Certainty Factor didapatkan nilai keakuratan sebesar $80 \%$ dan hasil pengujian dengan metode Dempster Shafer yaitu sebesar $85 \%$. Sehingga dapat disimpulkan bahwa dalam penelitian ini metode Dempster Shafer lebih akurat dibanding dengan metode Certainty Factor[10].

Penelitian tentang perbandingan metode Cetainty Factor dan Dempster Shafer pada sistem pakar penyakit anjing menggunakan 17 data penyakit, serta 10 data kasus yang digunakan sebagai bahan uji. Pada penelitian ini data didapatkan dari seorang pakar dokter hewan. Metode Dempster Shafer memiliki tingkat keakurasian yang lebih tinggi yaitu $76 \%$ dibandingkan metode Certainty Factor yang memiliki tingkat keakurasian sebesar 73\%[11].

Penelitian tentang analisis perbandingan sistem pakar dengan metode Bayesian Network dan Dempster Shafer pada sistem pakar diagnosis penyakit mata. Pada 
penelitian ini terdapat 6 jenis penyakit mata. Hasil yang didapatkan bahwa tingkat akurasi sistem dengan menggunakan metode Bayesian Network dan metode Dempster Shafer sama yaitu sebesar $85,7 \%$ sehingga dapat disimpulkan bahwa kedua metode tersebut dalam penelitian ini sama baiknya[12].

Berdasarkan dari tinjauan pustaka penelitian terdahulu yang telah dilakukan, maka penulis ingin membuat sistem pakar yang dapat mendiagnosis penyakit pada ayam dengan 10 jenis penyakit yang disebabkan oleh bakteri dan virus menggunakan metode Dempster Shafer. Sistem pakar ini akan dibangun pada platform Android. Nilai kepercayaan suatu gejala didapatkan dari 3 pakar dokter hewan yaitu drh. Taufik Eko Budianto yaitu dokter hewan pada Pusat Kesehatan Hewan (PUSKESWAN) Aikmel Kabupaten Lombok Timur, drh. Heru Rachmadi kepala bidang kesehatan hewan di Dinas Peternakan dan Kesehatan Hewan Kabupaten Lombok Timur, drh. Rodiah M.Si dosen Fakultas Peternakan Universitas Mataram. Fitur yang diberikan sistem yaitu pengguna atau peternak dapat melakukan proses diagnosis berdasarkan gejalagejala yang diberikan sehingga mengetahui penyakit yang diderita ayam serta dapat melihat informasi mengenai penyakit dan riwayat penyakit yang diderita ayam dengan pencengahan dan solusi pengobatan dari penyakit tersebut.

\section{B. Dasar Teori}

\section{B.1. Dempster Shafer}

Teori Dempster Shafer menggunakan dua besaran yaitu Belief dan Plausibility. Belief (Bel) merupakan bobot kepercayaan atau ukuran kepastian dari suatu evidence (gejala) dalam menghitung suatu himpunan proporsisi (benar atau salah) sedangkan ukuran ketidakpercayaan atau ketidakpastian terhadap suatu evidence disebut dengan Plausibility (Pls). Jika bernilai 0 maka menunjukkan tidak adanya suatu gejala, dan jika bernilai 1 maka menunjukkan kepastian dari gejala tersebut. Keberdaan nilai Plausibility akan mengurangi tingkat kepastian dari suatu evidence. Dimisalkan X merupakan suatu penyakit yang diderita, maka jika yakin terdiagnosis penyakit $\mathrm{X}$ dapat dikatakan bahwa nilai $\operatorname{Bel}(\mathrm{X})=1$, sehingga nilai dari $P l s(\mathrm{X})=0$. Fungsi Belief diformulasikan seperti pada Persamaan (1) dan fungsi Plausibility diformulasikan seperti pada Persamaan (2)[18].

$$
\begin{aligned}
& \operatorname{Bel}(\mathrm{X})=\sum_{\mathrm{Y} \subseteq \mathrm{X}} m_{1}(\mathrm{X}) \\
& \operatorname{PIs}(\mathrm{X})=1-\operatorname{Bel}(X)=1-\sum_{\mathrm{Y} \subseteq \mathrm{X}} m_{1}(\mathrm{X})
\end{aligned}
$$

dimana:

$$
\begin{aligned}
& \mathrm{X}=\text { Penyakit yang mengalami gejala } 1 \\
& \mathrm{Y} \quad=\text { Penyakit yang mengalami gejala } 2 \\
& \operatorname{Bel}(\mathrm{X})=\operatorname{Belief}(\mathrm{X}) \text {, artinya nilai kepercayaan } \\
& \text { atau kepastian penyakit } X \text { yang }
\end{aligned}
$$

$$
\mathrm{m}_{1}(\mathrm{X})=\begin{aligned}
& \text { Mass function atau tingkat } \\
& \text { kepercayaan dari evidence }(\mathrm{X})
\end{aligned}
$$

Mass function (m) dalam teori Dempster Shafer adalah tingkat kepercayaan dari suatu evidence. Mass function (m) diformulasikan pada Persamaan (3).

$$
\mathrm{m} 3(\mathrm{Z})=\frac{\sum \mathrm{X} \cap \mathrm{Y}=\mathrm{Z} \mathrm{m} 1(\mathrm{X}) \cdot \mathrm{m} 2(\mathrm{Y})}{1-\sum \mathrm{X} \cap \mathrm{Y}=\varnothing \mathrm{m} 1(\mathrm{X}) \cdot \mathrm{m} 2(\mathrm{Y})}
$$

dimana:

$\mathrm{m} 3(\mathrm{Z})=$ Mass function dari evidence $(\mathrm{Z})$, di mana $\mathrm{Z}$ adalah nilai densitas baru hasil irisan dari $\mathrm{m} 1(\mathrm{X})$ dan $\mathrm{m} 2(\mathrm{Y})$ dibagi dengan 1 dikurangi irisan kosong $(\varnothing)$ dari $\mathrm{m} 1(\mathrm{X})$ dan $\mathrm{m} 2(\mathrm{Y})$.

$\mathrm{m} 1(\mathrm{X})=$ Mass function atau tingkat kepercayaan dari evidence $(\mathrm{X})$, di mana $\mathrm{X}$ adalah penyakit yang mengalami gejala 1

$\mathrm{m} 2(\mathrm{Y})=$ Mass function atau tingkat kepercayaan dari evidence (Y), di mana $\mathrm{Y}$ adalah penyakit yang mengalami gejala 2

Akuisisi pengetahuan pada metode Dempster Shafer dilakukan dengan megumpulkan data dari berbagai referensi dan wawancara. Nilai kepercayaan terhadap suatu gejala didapat dengan cara memberikan kuesioner kepada tiga pakar dokter hewan. Nilai alternatif jawaban yang bisa dipilih pakar untuk mengisi kuesioner yaitu seperti pada Tabel I.

TABEL I. NiLAI ALTERNATIF JAWABAN KUESIONER[18]

\begin{tabular}{|l|c|}
\hline $\begin{array}{c}\text { Kepercayaan terhadap suatu } \\
\text { gejala }\end{array}$ & Nilai kepercayaan (Bobot) \\
\hline Sangat tidak setuju & 0.05 \\
\hline Tidak setuju & 0.25 \\
\hline Netral & 0.5 \\
\hline Setuju & 0.85 \\
\hline Sangat setuju & 1 \\
\hline
\end{tabular}

Hasil akhir dari nilai kepercayaan terhadap setiap gejala digunakan dalam perhitungan metode Dempster Shafer pada mesin inferensi. Hasil akhir dari nilai kepercayaan dihitung dengan Persamaan (4):

nilai akhir kepercayaan pernyataan $(\mathrm{x})=$ $\underline{\text { (nilai jawaban responden } 1+\cdots+\text { nilai jawaban responden } \mathrm{n} \text { ) }}$ jumlah responden

\section{B.2 Penyakit Ayam}

Beberapa penyakit ayam yang disebabkan oleh bakteri dan virus khususnya ayam broiler diantaranya sebagai berikut:

1. Newcastle Disease (ND) atau Tetelo

2. Avian influenza (AI) atau Flu Burung

3. Infectious Bursal Disease (IBD) atau Gumboro

4. Marek Disease

5. Infectious Bronchitis (IB)

6. Kolera

7. Berak Kapur (Pullorum)

8. Cronic Respiratory Disease (CRD)

9. Colibacillosis 


\section{SNOT atau Coryza}

\section{Proses Perhitungan}

Pada metode Dempster Shafer terdapat nilai densitas atau nilai kepastian terhadap suatu penyakit yang disebut dengan nilai belief. Nilai belief dari suatu gejala terhadap suatu penyakit yang diderita didapatkan berdasarkan pada pengetahuan dan pengalaman seorang pakar dalam mendiagnosis penyakit pada ayam. Nilai belief pada metode Dempster Shafer berada pada rentang 0 sampai dengan 1. Semakin tinggi nilai belief yang diberikan seorang pakar maka akan semakin tinggi kemungkinan nilai densitas yang akan dihasilkan. Nilai akhir kepercayaan gejala dapat dihitung dengan Persamaan (5).

Nilai akhir kepercayaan gejala $(X)=$

nilai belief pakar $1+$ nilai belief pakar $2+$ nilai belief pakar 3 3

\section{Metodologi PENELITIAN}

\section{A. Tahapan Penelitian}

Terdapat beberapa tahapan atau langkah yang dilakukan selama penelitian, langkah dalam proses penelitian yaitu mulai dari langkah studi literatur, pengumpulan data, hingga penarikan kesimpulan yang dijelaskan sesuai Gambar 1.

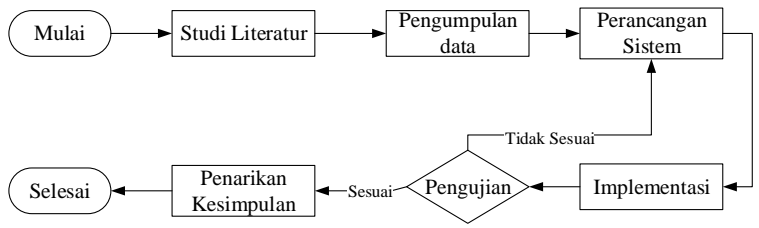

Gambar 1. Diagram alir tahapan penelitian sistem pakar diagnosis penyakit pada ayam.

Dari Gambar 1 dapat diuraikan beberapa tahapan penelitian yang dilakukan, yaitu :

\section{A.1. Studi Literatur}

Pada penelitian ini studi literatur dilakukan dengan mempelajari buku-buku, jurnal penelitian, skripsi maupun sumber lain yang berkaitan dengan penelitian. Dalam tahapan studi literatur hal yang dipelajari berkaitan dengan penyakit yang diderita ayam broiler dan metode Dempster Shafer guna mengetahui kelebihan serta kekurangannya, sehingga dapat dijadikan sebagai acuan untuk mengembangkan sistem yang akan dibangun.

\section{A.2. Pengumpulan/Akuisisi Data}

Pada tahapan ini, dilakukan dengan mewawancarai 3 orang pakar (dokter hewan). Informasi yang diperoleh dari hasil wawancara yaitu data penyakit dan gejala yang diderita ayam broiler serta data pencegahan dan solusi dalam menangani penyakit, nilai keyakinan gejala penyakit pada ayam diberikan oleh drh. Taufik Eko Budianto dan dua pakar lainnya membantu memberikan nilai belief.

\section{A.3. Perancangan Sistem}

Tahapan selanjutnya dilakukan perancangan arsitektur sistem serta perancangan desain interface sistem. Desain sistem ini akan menjadi acuan pada tahap implementasi.

\section{A.4. Implementasi}

Implementasi dilakukan dengan membangun program berdasarkan perancangan sistem yang telah dibuat pada langkah sebelumnya.

\section{A.5. Pengujian Sistem}

Pengujian dilakukan bertujuan untuk mengetahui kesesuaian atau kelayakan dari sistem yang telah dibangun. Pengujian yang dilakukan berupa pengujian akurasi sistem, pengujian black box, pengujian perhitungan teoritis dan pengujian kuisioner. Apabila dalam pengujian hasil yang ditampilkan oleh sistem tidak sesuai yang diharapkan atau terdapat masalah yang terjadi maka akan dilakukan analisa kembali mulai dari tahap perancangan sistem dan seterusnya hingga mendapatkan hasil yang sesuai pada sistem.

\section{A.6. Penarikan Kesimpulan}

Penarikan kesimpulan didapat berdasarkan dari kesesuaian sistem pada tahap pengujian dan telah mampu memberikan informasi yang sesuai dengan kebutuhan pengguna.

\section{B. Arsitektur Sistem Pakar Diagnosis Penyakit pada Ayam}

Perancangan arsitektur sistem pakar diagnosis penyakit pada ayam yang dapat dijelaskan ke dalam diagram yang ditampilkan pada Gambar 2.

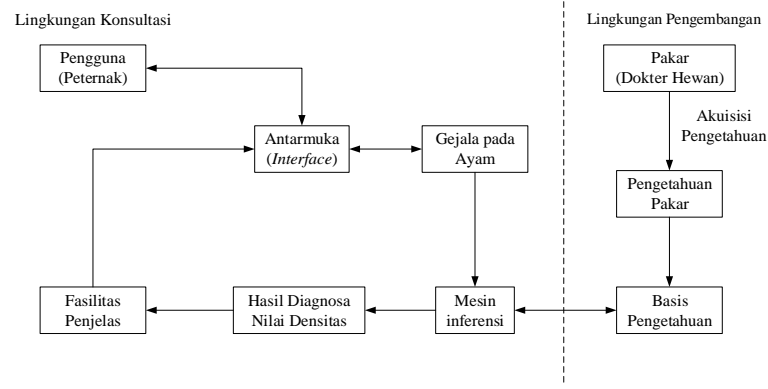

Gambar 2. Arsitektur sistem pakar diagnosis penyakit pada ayam.

Gambar 3 merupakan penjelasan untuk proses mesin inferensi. Mesin inferensi merupakan pola pemahaman dan penalaran yang digunakan untuk mendapatkan suatu hasil diagnosis dari data masukan yang ada. Pada sistem ini metode inferensi yang digunakan yaitu forward chaining, dengan memasukkan beberapa data gejala dan memperoleh suatu kesimpulan. Proses mesin inferensi dimulai dengan memilih gejala yang terlihat, dimana nilai belief dari setiap gejala telah diberikan oleh 3 orang pakar dokter hewan. Setelah memilih gejala, selanjutnya dilakukan perhitungan untuk memperoleh nilai plausibility. Langkah selanjutnya perhitungan dicari untuk mendapatkan nilai densitas baru. Perhitungan nilai densitas baru akan dilakukan secara berulang hingga gejala yang pengguna pilih telah habis dan 
nilai densitas akhir terbesar akan dijadikan sebagai hasil diagnosis penyakit pada ayam.

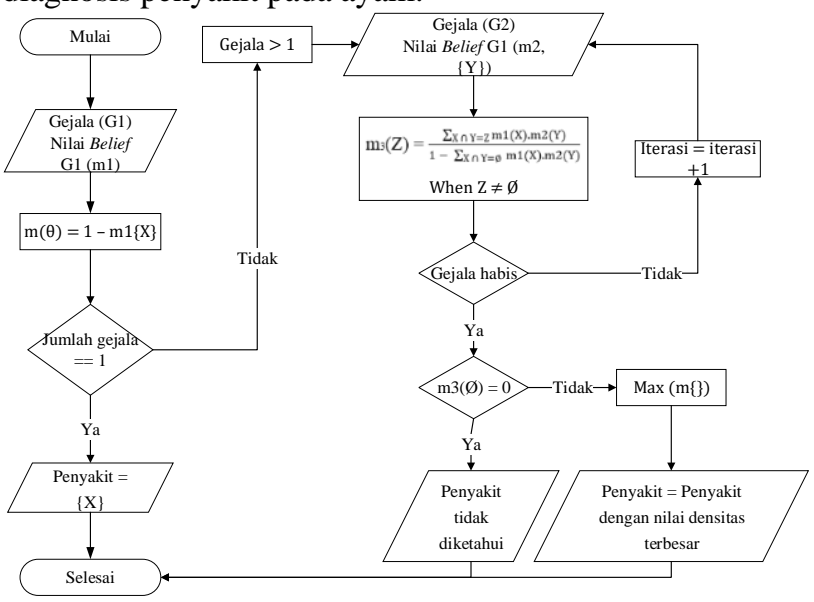

Gambar 3. Algoritma metode Dempster Shafer.

\section{HASIL DAN ANALISIS}

\section{A. Implementasi Sistem Pakar}

\section{A.1. Halaman Menu Diagnosis}

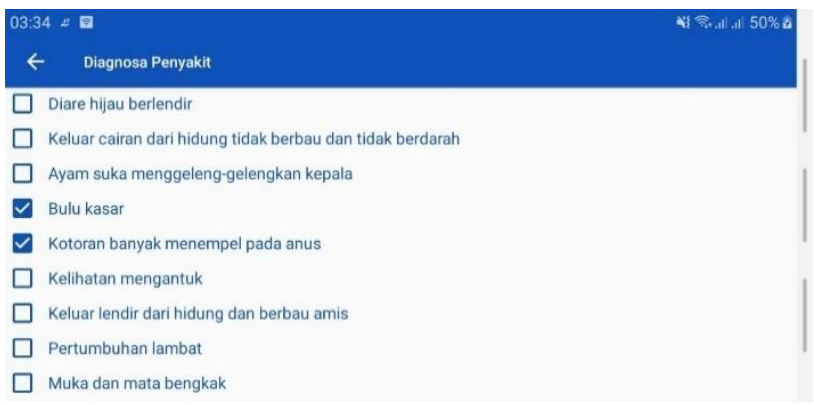

Gambar 4. Tampilan halaman menu diagnosis.

Gambar 4 merupakan halaman menu diagnosis yang menampilkan seluruh gejala penyakit yang diderita ayam. Pengguna dapat memilih gejala dengan cara mencentang kotak atau check box pada setiap gejala yang terdapat pada halaman diagnosis dan selanjutnya pengguna dapat menekan tombol diagnosis setelah memilih gejala pada bagian paling bawah untuk melihat hasil diagnosis yang telah dilakukan.

\section{A.2. Halaman Hasil Diagnosis}
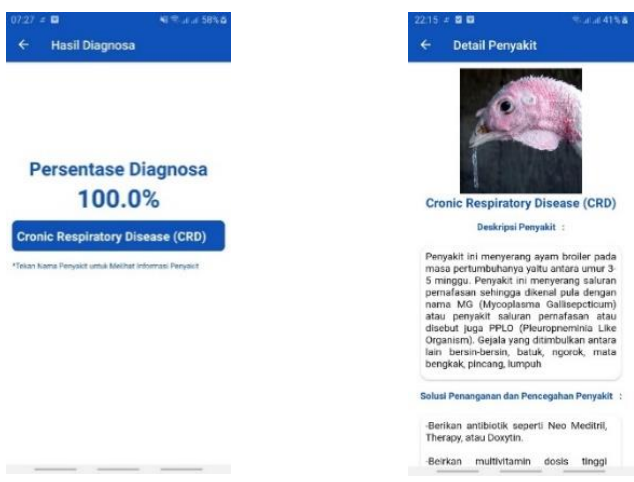

Gambar 5. Tampilan halaman hasil diagnosis.
Gambar 5 merupakan halaman hasil diagnosis yang menampilkan persentase dan kemungkinan penyakit yang diderita ayam. Jika pengguna menekan bagian nama penyakit, maka akan dialihkan ke halaman yang berisikan deskripsi serta solusi dan penanganan penyakit pada ayam tersebut.

\section{B. Pengujian Sistem \\ B.1. Pengujian Black Box}

Pengujian black box dalam sistem pakar diagnosis penyakit pada ayam dilakukan oleh 5 orang responden mahasiswa Teknik Informatika Universitas Mataram. Didapatkan hasil pengujian oleh seluruh responden pada fungsionalitas laman data penyakit, laman diagnosis, laman hasil diagnosis, laman riwayat hasil diagnosis, laman panduan penggunaan dan laman tentang aplikasi telah berjalan semestinya dengan tingkat kesesuaian 100\%. Hal tersebut berarti sistem sudah sesuai dengan yang diharapkan.

\section{B.2. Pengujian Kuisioner}

Pengujian kuisioner dilakukan oleh 30 responden yang terdiri dari 5 pegawai PUSKESWAN, 8 peternak dan 17 mahasiswa Teknik Informatika Universitas Mataram. Pengujian dilakukan guna mengetahui apakah sistem telah memiliki tampilan yang menarik, mudah digunakan, mampu mendiagnosis dengan baik dan akan digunakan kedepannya oleh peternak. Pengujian dilakukan dengan memberikan kuisioner yang berisikan 5 pertanyaan diantaranya yaitu :

1. Tampilan dari sistem pakar diagnosis awal penyakit ayam menarik dan mudah digunakan (user friendly).

2. Penggunaan warna dari tampilan serta jenis huruf yang digunakan pada sistem ini sudah sesuai.

3. Sistem pakar ini dapat memberikan informasi terkait solusi penanganan dan pencegahan penyakit pada ayam khususnya ayam broiler.

4. Sistem pakar ini dapat membantu pengguna dalam melakukan diagnosis penyakit yang dialami ayam dengan lebih mudah.

5. Anda akan tetap menggunakan sistem pakar ini untuk membantu mendiagnosis penyakit yang dialami ayam Anda pada waktu yang akan datang.

Nilai rata-rata (mean pi) dapat dihitung dengan Persamaan (6) $[18]$.

$$
\mu_{p i}=\frac{\sum S_{i} \cdot B_{i}}{n}
$$

dimana:

$\mu_{p i}:$ rata - rata skor setiap atribut pertanyaan

$\mathrm{S} i$ : jumlah responden yang memilih setiap atribut jawaban

$\mathrm{B} i$ : bobot setiap atribut pertanyaan

$\mathrm{N}$ : jumlah responden

Sedangkan untuk menghitung nilai MOS digunakan persamaan (7). 


$$
\operatorname{MOS}=\frac{\sum_{i=1}^{k} \mu_{p i}}{k}
$$

dimana:

MOS : total skor rata-rata seluruh atribut pertanyaan

$\mathrm{k} \quad$ : jumlah atribut pertanyaan

TABEL II. PENGUJIAN OLEH RESPONDEN YANG TIDAK MENGERTI SISTEM DENGAN PARAMETER MOS

\begin{tabular}{|c|c|c|c|c|c|c|c|c|}
\hline $\begin{array}{l}\mathbf{N} \\
\mathbf{0}\end{array}$ & Pertanyaan & SS & $\mathbf{S}$ & $\begin{array}{l}\mathbf{T} \\
\mathbf{T}\end{array}$ & $\begin{array}{l}\mathbf{T} \\
\mathbf{S}\end{array}$ & STS & Tot & $\begin{array}{c}\text { mean } \\
p i\end{array}$ \\
\hline 1 & Pertanyaan 1 & 12 & 1 & - & - & - & 13 & 4.92 \\
\hline 2 & Pertanyaan 2 & 13 & - & - & - & - & 13 & 5 \\
\hline 3 & Pertanyaan 3 & 12 & 1 & - & - & - & 13 & 4.92 \\
\hline 4 & Pertanyaan 4 & 13 & - & - & - & - & 13 & 5 \\
\hline 5 & Pertanyaan 5 & 11 & 2 & - & - & - & 13 & 4.84 \\
\hline \multirow{2}{*}{\multicolumn{8}{|c|}{ MOS (Mean Opinion Score) }} & 24.68 \\
\hline & & & & & & & & 4.93 \\
\hline
\end{tabular}

Pengujian kuisioner seperti pada Tabel II yang dilakukan pada responden yang tidak mengerti sistem yaitu pegawai PUSKESWAN dan peternak mendapatkan hasil pengujian dengan menggunakan parameter MOS sebesar 4.93 dari skala 5. Hal tersebut menunjukkan bahwa aplikasi sistem pakar diagnosis penyakit pada ayam yang dibangun sudah baik sesuai dengan rentang nilai MOS dengan bobot 4 sampai 5 yang dikategorikan baik (good).

TABEL III. PENGUJiAn OleH RESPONDEN YANG MENGERTI Sistem DENGAN PARAMETER MOS

\begin{tabular}{|c|c|c|c|c|c|c|c|c|}
\hline $\begin{array}{l}\mathbf{N} \\
\mathbf{0}\end{array}$ & Pertanyaan & SS & $\mathbf{S}$ & $\begin{array}{l}\mathbf{T} \\
\mathbf{T}\end{array}$ & $\begin{array}{l}\text { T } \\
\mathbf{S}\end{array}$ & STS & Tot & $\begin{array}{c}\text { mean } \\
p i\end{array}$ \\
\hline 1 & Pertanyaan 1 & 7 & 10 & - & - & - & 17 & 4.41 \\
\hline 2 & Pertanyaan 2 & 5 & 11 & 1 & - & - & 17 & 4.05 \\
\hline 3 & Pertanyaan 3 & 9 & 8 & - & - & - & 17 & 4.52 \\
\hline 4 & Pertanyaan 4 & 9 & 7 & 1 & - & - & 17 & 4.47 \\
\hline 5 & Pertanyaan 5 & 4 & 8 & 5 & - & - & 17 & 3.94 \\
\hline \multirow{2}{*}{\multicolumn{8}{|c|}{\begin{tabular}{c|c|c|c|c}
44 & 7 & - & - & 85 \\
& MOS (Mean Opinion Score) \\
\end{tabular}}} & 21.39 \\
\hline & & & & & & & & 4.27 \\
\hline
\end{tabular}

Pengujian kuisioner seperti pada Tabel III yang dilakukan pada responden yang mengerti sistem yaitu mahasiswa Teknik Informatika Universitas Mataram didapatkan hasil pengujian dengan menggunakan parameter MOS sebesar 4.27 dari skala 5. Hal tersebut menunjukkan bahwa aplikasi sistem pakar diagnosis penyakit pada ayam yang dibangun sudah baik sesuai dengan rentang nilai MOS dengan bobot 4 sampai 5 yang dikategorikan baik (good).

Dari kedua hasil pengujian kuisioner didapatkan bahwa aplikasi sistem pakar diagnosis penyakit ayam yang dibangun sudah baik karena mendapatkan hasil dengan sebesar 4.93 dan 4.27 dari skala 5. Hal tersebut dikategorikan baik (good) dalam rentang bobot parameter MOS. Dengan demikian sistem yang dibangun telah memiliki tampilan yang menarik dan mudah digunakan serta mampu membantu dalam mendiagnosis penyakit yang dapat diderita oleh ayam dan juga bagi peternak dikemudian hari akan terus menggunakan aplikasi sistem pakar diagnosis penyakit pada ayam.

\section{B.3. Pengujian Teoritis}

Pengujian perhitungan teoritis dilakukan pada salah satu contoh kasus yang diberikan pakar seperti pada Tabel IV.

TABEL IV. Gejala Pengujian Perhitungan TeOritis

\begin{tabular}{|c|c|c|}
\hline Gejala & Nama Penyakit & Bobot \\
\hline \multirow{4}{*}{ Diare } & (P02) Avian Influenza (AI) atau Flu Burung & 0,90 \\
\cline { 2 - 3 } & (P04) Marek Disease & 0,85 \\
\cline { 2 - 3 } & (P05) Infections Bronchitis (IB) & 0,85 \\
\cline { 2 - 3 } & (P09) Colibacillosis & 0,95 \\
\hline \multirow{3}{*}{$\begin{array}{c}\text { Tampak } \\
\text { lesu }\end{array}$} & (P01) Newcastel Disease (ND) & 0,90 \\
\cline { 2 - 3 } & (P03) Infectious Bursal Disease (IBD) atau & 0,85 \\
\cline { 2 - 3 } Gumboro & 0,73 \\
\cline { 2 - 3 } & (P06tions Bronchitis (IB) Kolera & 0,73 \\
\hline $\begin{array}{c}\text { Bulu } \\
\text { kasar }\end{array}$ & P(09) Colibacillosis & 0,78 \\
\hline $\begin{array}{c}\text { Kotoran } \\
\text { banyak } \\
\text { menempel } \\
\text { pada anus }\end{array}$ & (P09) Colibacillosis & 0,90 \\
\hline
\end{tabular}

a. Gejala 1: Diare

$\mathrm{m} 1\{\mathrm{P} 02, \mathrm{P} 04, \mathrm{P} 05, \mathrm{P} 09\}=\frac{0,90+0,85+0.85+0,95}{4}=0,8875$

$\mathrm{m} 1\{\theta\}=1-0.8875=0.1125$

b. Gejala 2: Tampak lesu

$$
\begin{aligned}
\mathrm{m} 2\{\mathrm{P} 01, \mathrm{P} 03, \mathrm{P} 05, \mathrm{P} 06, \mathrm{P} 09\} & =\frac{0,90+0,85+0,73+0,73+0,78}{5} \\
& =0.798
\end{aligned}
$$

$\mathrm{m} 2\{\theta\}=1-0.798=0.202$

TABEL V. NILAI ATURAN KOMBINASI M3

\begin{tabular}{|c|c|c|}
\hline \multirow{2}{*}{$\mathbf{m 1}$} & \multicolumn{2}{|c|}{$\mathbf{m 2}$} \\
\cline { 2 - 3 } & $\mathrm{m} 2\{\mathrm{P} 01, \mathrm{P} 03, \mathrm{P} 05, \mathrm{P} 06, \mathrm{P} 09\}$ & $\mathrm{m} 2\{\theta\}=$ \\
& $=0.798$ & 0.202 \\
\hline & & $\{\mathrm{P} 02, \mathrm{P} 04$ \\
$\mathrm{m} 1\{\mathrm{P} 02, \mathrm{P} 04, \mathrm{P} 05, \mathrm{P} 09\}$ & $\{\mathrm{P} 05, \mathrm{P} 09\}=0.8875 \mathrm{x}$ & $, \mathrm{P} 05, \mathrm{P} 09$ \\
$=0.8875$ & $0.798=0.708225$ & $0.8875 \mathrm{x}$ \\
& & $0.202=$ \\
& & 0,179275 \\
\hline & & $\{\theta\}=$ \\
$\mathrm{m} 1\{\theta\}=0.1125$ & $\{\mathrm{P} 01, \mathrm{P} 03, \mathrm{P} 05, \mathrm{P} 06, \mathrm{P} 09\}=$ & $0.1125 \mathrm{x}$ \\
& $0.1798 \times 0.1125=$ & $0.202=$ \\
& 0.089775 & 0,022725 \\
\hline
\end{tabular}

Sehingga dapat dihitung sebagai berikut:

$$
\begin{aligned}
& \mathrm{m} 3\{\mathrm{P} 05, \mathrm{P} 09\}=\frac{0,708225}{1-0}=0.708225 \\
& \mathrm{~m} 3\{\mathrm{P} 02, \mathrm{P} 04, \mathrm{P} 05, \mathrm{P} 09\}=\frac{0,179275}{1-0}=0,179275 \\
& \mathrm{~m} 3\{\mathrm{P} 01, \mathrm{P} 03, \mathrm{P} 05, \mathrm{P} 06, \mathrm{P} 09\}=\frac{0,089775}{1-0}=0,089775 \\
& \mathrm{~m} 3\{\theta\}=1-(0.708225+0,179275+0,089775) \\
& =0,022725
\end{aligned}
$$

c. Gejala 3: Bulu kasar

$\mathrm{m} 4\{\mathrm{P} 09\}=0,90$

$\mathrm{m} 4\{\theta\}=1-0.90=0,1$ 
TABEL VI. NILAI ATURAN Kombinasi M5

\begin{tabular}{|l|l|l|}
\hline \multirow{2}{*}{$\mathbf{m} 3$} & \multicolumn{1}{|c|}{$\mathbf{m 4}$} \\
\cline { 2 - 3 } & $\begin{array}{l}\mathrm{m} 4\{\mathrm{P} 09\} \\
=0.90\end{array}$ & \multicolumn{1}{c|}{$\mathrm{m} 4\{\theta\}=0.1$} \\
\hline & $\begin{array}{l}\{\mathrm{P} 09\}= \\
0.708225\end{array}$ & \\
& $\mathrm{x} 0.90=$ & $\{\mathrm{P} 05, \mathrm{P} 09\}=0.708225$ \\
$\mathrm{~m} 3\{\mathrm{P} 05, \mathrm{P} 09\}=0.708225$ & 0.6374025 & $\mathrm{x} 0.1=0.0708225$ \\
$\mathrm{~m} 3\{\mathrm{P} 02, \mathrm{P} 04, \mathrm{P} 05, \mathrm{P} 09\}=$ & $\{\mathrm{P} 09\}=$ & $\{\mathrm{P} 02, \mathrm{P} 04, \mathrm{P} 05, \mathrm{P} 09\}=$ \\
0,179275 & 0,179275 & $0,179275 \times 0.1=$ \\
$\mathrm{m} 3\{\mathrm{P} 01, \mathrm{P} 03, \mathrm{P} 05, \mathrm{P} 06, \mathrm{P} 09\}$ & $\mathrm{x} 0.90=$ & 0.0179275 \\
$=0.089775$ & 0.1613475 & $\{\mathrm{P} 01, \mathrm{P} 03, \mathrm{P} 05, \mathrm{P} 06, \mathrm{P} 09\}$ \\
& $\{\mathrm{P} 09\}=$ & $=0.089775 \times 0.1=$ \\
& 0.089775 & 0.0089775 \\
& $\mathrm{x} 0.90=$ & \\
& 0.0807975 & \\
\hline & $\{\mathrm{P} 09\}=$ & \\
$\mathrm{m} 3\{\theta\}=0,022725$ & 0,022725 & $\{\theta\}=0,022725 \times 0.1=$ \\
& $\mathrm{x} 0.90=$ & 0,0022725 \\
& 0.0204525 & \\
\hline
\end{tabular}

Sehingga dapat dihitung sebagai berikut:

$$
\begin{aligned}
& \mathrm{m} 5\{\mathrm{P} 09\}=\frac{0.6374025+0.1613475+0.0807975+0.0204525}{1-0}=0.9 \\
& \mathrm{~m} 5\{\mathrm{P} 05, \mathrm{P} 09\}=\frac{0.0708225}{1-0}=0.0708225 \\
& \mathrm{~m} 5\{\mathrm{P} 02, \mathrm{P} 04, \mathrm{P} 05, \mathrm{P} 09\}=\frac{0.0179275}{1-0}=0.0179275 \\
& \mathrm{~m} 5\{\mathrm{P} 01, \mathrm{P} 03, \mathrm{P} 05, \mathrm{P} 06, \mathrm{P} 09\}=\frac{0.0089775}{1-0}=0.0089775 \\
& \mathrm{~m} 5\{\theta\}=1-(0.9+0.0708225+0.0179275+ \\
& 0.0089775)=0,0022725 \\
& \text { d. Gejala 4: Kotoran banyak menempel pada anus } \\
& \mathrm{m} 6\{\mathrm{P} 09\}=0.78 \\
& \mathrm{~m} 6\{\theta\}=1-0.78=0.22
\end{aligned}
$$

\begin{tabular}{|c|c|c|}
\hline \multirow[b]{2}{*}{ m5 } & \multicolumn{2}{|r|}{ m6 } \\
\hline & $\begin{array}{c}\mathrm{m} 6\{\mathrm{P} 09\}= \\
0.78\end{array}$ & $\mathrm{~m} 6\{\theta\}=0.22$ \\
\hline $\begin{array}{l}\mathrm{m} 5\{\mathrm{P} 09\}=0.9 \\
\mathrm{~m} 5\{\mathrm{P} 05, \mathrm{P} 09\}= \\
0.0708225 \\
\mathrm{~m} 5\{\mathrm{P} 02, \mathrm{P} 04, \mathrm{P} 05, \mathrm{P} 09\}= \\
0,0179275 \\
\mathrm{~m} 5\{\mathrm{P} 01, \mathrm{P} 03, \mathrm{P} 05, \mathrm{P} 06, \mathrm{P} 09\} \\
=0.0089775\end{array}$ & $\begin{array}{l}\{\mathrm{P} 09\}= \\
0.9 \times 0.78= \\
0.702 \\
\{\mathrm{P} 09\}= \\
0.0708225 \\
\times 0.78= \\
0.05524155 \\
\{\mathrm{P} 09\}= \\
0,0179275 \\
\mathrm{x} 0.78= \\
0.01398345 \\
\{\mathrm{P} 09\}= \\
0.0089775 \\
\mathrm{x} 0.78= \\
0.00700245 \\
\end{array}$ & $\begin{array}{l}\{\mathrm{P} 09\}=0.9 \times 0.22= \\
0.198 \\
\{\mathrm{P} 05, \mathrm{P} 09\}= \\
0.0708225 \times 0.22= \\
0.01558095 \\
\{\mathrm{P} 02, \mathrm{P} 04, \mathrm{P} 05, \mathrm{P} 09\}= \\
0,0179275 \times 0.22= \\
0.00394405 \\
\{\mathrm{P} 01, \mathrm{P} 03, \mathrm{P} 05, \mathrm{P} 06, \mathrm{P} 09\} \\
=0.0089775 \times 0.22 \\
=0.00197505\end{array}$ \\
\hline $\mathrm{m} 3\{\theta\}=0,0022725$ & $\begin{array}{l}\text { P09 }\}= \\
0,0022725 \\
x 0.78= \\
0.00177255\end{array}$ & $\begin{aligned}\{\theta\} & =0,0022725 \times 0.22 \\
& =0.00049995\end{aligned}$ \\
\hline
\end{tabular}

TABEL VII. NILAI ATURAN KOMBINASI M7

Sehingga dapat dihitung sebagai berikut:

$\mathrm{m} 7\{\mathrm{P} 09\}=$

$\underline{0.702+0.05524155+0.01398345+0.00700245+0.198+0.00177255}$

$=0.978$

$1-0$

$\mathrm{m} 7\{\mathrm{P} 05, \mathrm{P} 09\}=\frac{0.01558095}{1-0}=0.01558095$ $\mathrm{m} 7\{\mathrm{P} 02, \mathrm{P} 04, \mathrm{P} 05, \mathrm{P} 09\}=\frac{0.00394405}{1-0}=0.00394405$ $\mathrm{m} 7\{\mathrm{P} 01, \mathrm{P} 03, \mathrm{P} 05, \mathrm{P} 06, \mathrm{P} 09\}=\frac{0.00197505}{1-0}=0.00197505$ $\mathrm{m} 7\{\theta\}=1-(0.978+0.01558095+0.00394405+0.00197$ $505)=0.00049995$

Berdasarkan 4 gejala yang dimasukkan maka nilai densitas yang paling kuat ada pada penyakit ayam yaitu P09 Colibacillosis dengan tingkat kepercayaan (densitas) sebesar 0.978 atau dengan presentase sebesar $97.8 \%$.

Gambar 6 merupakan tampilan hasil diagnosis dengan contoh kasus yang diberikan pakar seperti pada Tabel III. Hasil yang ditampilkan sesuai dengan hasil perhitungan pengujian teoritis yaitu dengan akurasi sebesar 97.8\% terkena penyakit Colibacillosis.
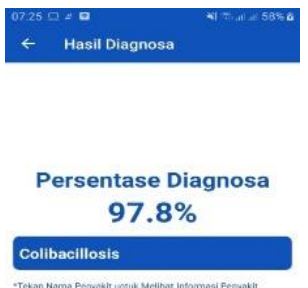

Gambar 6. Tampilan hasil diagnosis pengujian pada sistem.

\section{B.4. Pengujian Akurasi}

Pengujian akurasi pada sistem pakar diagnosis penyakit ayam dilakukan oleh 3 pakar dokter hewan. Pada pengujian ini 30 contoh kasus diberikan oleh drh. Heru Rachmadi. Pengujian akurasi selengkapnya dapat diunduh pada tautan https://drive.google.com/file/d/1bfJJpAOgFpLSibZNnSe HPTiAp4bsxE_r/view?usp=sharing.

Perbandingan hasil pengujian pakar pertama dengan sistem dapat dilihat pada Tabel VIII, perbandingan hasil pengujian pakar kedua dengan sistem dapat dilihat pada Tabel IX, dan perbandingan hasil pengujian pakar ketiga dengan sistem dapat dilihat pada Tabel X.

TABEL VIII. Perbandingan Hasil Pengujian Pakar Pertama DENGAN SISTEM

\begin{tabular}{|c|l|l|c|}
\hline $\begin{array}{c}\text { Pengujian } \\
\text { ke - }\end{array}$ & $\begin{array}{l}\text { Hasil Diagnosis } \\
\text { Pakar Pertama }\end{array}$ & \multicolumn{1}{|c|}{$\begin{array}{c}\text { Hasil Diagnosis } \\
\text { Sistem }\end{array}$} & Ket \\
\hline 1 & CRD & CRD 100.0\% & Valid \\
\hline 2 & $\begin{array}{l}\text { IBD atau } \\
\text { Gumboro }\end{array}$ & Marek Disease 100.0\% & Invalid \\
\hline 3 & $\begin{array}{l}\text { Berak Kapur } \\
(\text { Pullorum })\end{array}$ & Colibacillosis 97.8\% & Invalid \\
\hline 4 & Kolera Kapur & Kolera 100.0\% & Valid \\
\hline 5 & CRD atibacillosis 97.8\% & Invalid \\
\hline 6 & $\begin{array}{l}\text { Berak atau Coryza } \\
(\text { Pullorum })\end{array}$ & $\begin{array}{l}\text { SNOT atid } \\
100.0 \%\end{array}$ \\
\hline 7 & $\begin{array}{l}\text { SNOT atau } \\
\text { Coryza }\end{array}$ & $\begin{array}{l}\text { SNOT atau Coryza } \\
100.0 \%\end{array}$ & Valid \\
\hline
\end{tabular}




\begin{tabular}{|c|c|c|c|}
\hline 9 & CRD & CRD $100.0 \%$ & Valid \\
\hline 10 & CRD & CRD 100.0\% & Valid \\
\hline 11 & ND atau Tetelo & ND atau Tetelo $100.0 \%$ & Valid \\
\hline 12 & $\begin{array}{l}\text { SNOT atau } \\
\text { Coryza }\end{array}$ & $\begin{array}{lll}\text { SNOT } & \text { atau } & \text { Coryza } \\
99.95 \% & & \\
\end{array}$ & Valid \\
\hline 13 & Marek Disease & Marek Disease $100.0 \%$ & Valid \\
\hline 14 & Marek Disease & Marek Disease $100.0 \%$ & Valid \\
\hline 15 & Marek Disease & Marek Disease $100.0 \%$ & Valid \\
\hline 16 & $\begin{array}{l}\text { IBD atau } \\
\text { Gumboro }\end{array}$ & $\begin{array}{l}\text { IBD atau Gumboro } \\
93.82 \%\end{array}$ & Valid \\
\hline 17 & $\begin{array}{l}\text { IBD atau } \\
\text { Gumboro }\end{array}$ & $\begin{array}{l}\text { IBD atau Gumboro } \\
86.21 \%\end{array}$ & Valid \\
\hline 18 & $\begin{array}{l}\text { IBD atau } \\
\text { Gumboro }\end{array}$ & $\begin{array}{l}\text { IBD atau Gumboro } \\
81.02 \%\end{array}$ & Valid \\
\hline 19 & $\begin{array}{l}\text { AI atau Flu } \\
\text { Burung }\end{array}$ & $\begin{array}{lll}\text { AI atau Flu Burung } \\
100.0 \%\end{array}$ & Valid \\
\hline 20 & $\begin{array}{l}\text { AI atau Flu } \\
\text { Burung }\end{array}$ & $\begin{array}{lll}\text { AI atau Flu } & \text { Burung } \\
100.0 \% & & \\
\end{array}$ & Valid \\
\hline 21 & $\begin{array}{l}\text { AI atau Flu } \\
\text { Burung }\end{array}$ & $\begin{array}{lll}\text { AI atau Flu } & \text { Burung } \\
100.0 \% & & \\
\end{array}$ & Valid \\
\hline 22 & $\begin{array}{l}\text { SNOT atau } \\
\text { Coryza }\end{array}$ & $\begin{array}{lll}\text { SNOT atau } & \text { Coryza } \\
100.0 \% & & \\
\end{array}$ & Valid \\
\hline 23 & $\begin{array}{l}\text { SNOT atau } \\
\text { Coryza }\end{array}$ & $\begin{array}{lll}\text { SNOT atau } & \text { Coryza } \\
99.99 \% & & \\
\end{array}$ & Valid \\
\hline 24 & ND atau Tetelo & ND atau Tetelo $100.0 \%$ & Valid \\
\hline 25 & ND atau Tetelo & ND atau Tetelo $100.0 \%$ & Valid \\
\hline 26 & ND atau Tetelo & ND atau Tetelo $100.0 \%$ & Valid \\
\hline 27 & ND atau Tetelo & ND atau Tetelo $100.0 \%$ & Valid \\
\hline 28 & $\begin{array}{l}\text { AI atau Flu } \\
\text { Burung }\end{array}$ & $\begin{array}{l}\text { AI atau Flu Burung } \\
100.0 \%\end{array}$ & Valid \\
\hline 29 & $\begin{array}{l}\text { AI atau Flu } \\
\text { Burung }\end{array}$ & $\begin{array}{l}\text { AI atau Flu Burung } \\
100.0 \%\end{array}$ & Valid \\
\hline 30 & $\begin{array}{l}\text { IBD atau } \\
\text { Gumboro, } \\
\text { Marek Disease }\end{array}$ & Marek Disease $100.0 \%$ & Invalid \\
\hline
\end{tabular}

Berdasarkan hasil pengujian antara pakar pertama dan sistem didapatkan 26 kasus yang sesuai dan 4 kasus yang tidak sesuai yaitu pada kasus ke-2, ke-3, ke-6 dan ke-30.

Selanjutnya dihitung hasil tangkat kesesuaian sistem dengan contoh kasus Tabel VII yaitu sebagai berikut :

Nilai kesesuaian pakar pertama $=\frac{26}{30} \times 100 \%=86,67 \%$

Namun apabila diasumsikan pada kasus ke-30 diagnosis termasuk valid karena merupakan salah satu himpunan bagian dari diagnosis penyakit yang diberikan pakar maka hasil tingkat kesesuaian pada contoh kasus Tabel VIII yaitu sebagai berikut :

Nilai kesesuaian pakar pertama $=\frac{27}{30} \times 100 \%=90 \%$

TABEL IX. Perbandingan Hasil Pengujian Pakar Kedua DENGAN SISTEM

\begin{tabular}{|c|l|l|c|}
\hline $\begin{array}{c}\text { Pengujian } \\
\text { ke - }\end{array}$ & $\begin{array}{l}\text { Hasil Diagnosis } \\
\text { Pakar Kedua }\end{array}$ & \multicolumn{1}{|c|}{$\begin{array}{c}\text { Hasil Diagnosis } \\
\text { Sistem }\end{array}$} & Ket \\
\hline 1 & CRD & CRD 100.0\% & Valid \\
\hline 2 & Marek Disease & Marek Disease 100.0\% & Valid \\
\hline 3 & Colibacillosis & Colibacillosis 97.8\% & Valid \\
\hline 4 & Kolera & Kolera 100.0\% & Valid \\
\hline 5 & CRD & CRD 100.0\% & Valid \\
\hline 6 & Colibacillosis & Colibacillosis 97.8\% & Valid \\
\hline 7 & $\begin{array}{l}\text { SNOT atau } \\
\text { Coryza }\end{array}$ & $\begin{array}{l}\text { SNOT atau Coryza } \\
100.0 \%\end{array}$ & Valid \\
\hline 8 & $\begin{array}{l}\text { SNOT atau } \\
\text { Coryza }\end{array}$ & $\begin{array}{l}\text { SNOT atau Coryza } \\
100.0 \%\end{array}$ & Valid \\
\hline 9 & CRD & CRD 100.0\% & Valid \\
\hline 10 & CRD & CRD 100.0\% & Valid \\
\hline
\end{tabular}

\begin{tabular}{|c|c|c|c|}
\hline 11 & ND atau Tetelo & $\begin{array}{l}\text { ND atau Tetelo } \\
100.0 \%\end{array}$ & Valid \\
\hline 12 & $\begin{array}{l}\text { SNOT atau } \\
\text { Coryza }\end{array}$ & $\begin{array}{lll}\text { SNOT atau } & \text { Coryza } \\
99.95 \% & & \\
\end{array}$ & Valid \\
\hline 13 & Marek Disease & Marek Disease $100.0 \%$ & Valid \\
\hline 14 & Marek Disease & Marek Disease $100.0 \%$ & Valid \\
\hline 15 & Marek Disease & Marek Disease $100.0 \%$ & Valid \\
\hline 16 & $\begin{array}{l}\text { IBD atau } \\
\text { Gumboro }\end{array}$ & $\begin{array}{l}\text { IBD atau Gumboro } \\
93.82 \%\end{array}$ & Valid \\
\hline 17 & Marek Disease & $\begin{array}{l}\text { IBD atau Gumboro } \\
86.21 \%\end{array}$ & Invalid \\
\hline 18 & $\begin{array}{l}\text { IBD atau } \\
\text { Gumboro }\end{array}$ & $\begin{array}{l}\text { IBD atau Gumboro } \\
81.02 \%\end{array}$ & Valid \\
\hline 19 & $\begin{array}{l}\text { AI atau Flu } \\
\text { Burung }\end{array}$ & $\begin{array}{l}\text { AI atau Flu Burung } \\
100.0 \%\end{array}$ & Valid \\
\hline 20 & $\begin{array}{l}\text { AI atau Flu } \\
\text { Burung }\end{array}$ & $\begin{array}{l}\text { AI atau Flu Burung } \\
100.0 \%\end{array}$ & Valid \\
\hline 21 & $\begin{array}{l}\text { AI atau Flu } \\
\text { Burung }\end{array}$ & $\begin{array}{l}\text { AI atau Flu Burung } \\
100.0 \%\end{array}$ & Valid \\
\hline 22 & $\begin{array}{l}\text { SNOT atau } \\
\text { Coryza }\end{array}$ & $\begin{array}{l}\text { SNOT atau Coryza } \\
100.0 \%\end{array}$ & Valid \\
\hline 23 & $\begin{array}{l}\text { SNOT atau } \\
\text { Coryza }\end{array}$ & $\begin{array}{lll}\text { SNOT atau } & \text { Coryza } \\
99.99 \% & & \\
\end{array}$ & Valid \\
\hline 24 & ND atau Tetelo & ND atau Tetelo $100.0 \%$ & Valid \\
\hline 25 & ND atau Tetelo & ND atau Tetelo $100.0 \%$ & Valid \\
\hline 26 & ND atau Tetelo & ND atau Tetelo $100.0 \%$ & Valid \\
\hline 27 & ND atau Tetelo & ND atau Tetelo $100.0 \%$ & Valid \\
\hline 28 & $\begin{array}{l}\text { AI atau Flu } \\
\text { Burung }\end{array}$ & $\begin{array}{l}\text { AI atau Flu Burung } \\
100.0 \%\end{array}$ & Valid \\
\hline 29 & $\begin{array}{l}\text { AI atau Flu } \\
\text { Burung }\end{array}$ & $\begin{array}{l}\text { AI atau Flu Burung } \\
100.0 \%\end{array}$ & Valid \\
\hline 30 & Marek Disease & Marek Disease $100.0 \%$ & Valid \\
\hline
\end{tabular}

Berdasarkan hasil pengujian antara pakar kedua dan sistem didapatkan 29 kasus yang sesuai dan 1 kasus yang tidak sesuai pada kasus ke-17. Selanjutnya dihitung hasil tangkat kesesuaian sistem dengan contoh kasus Tabel IX yaitu sebagai berikut :

Nilai kesesuaian pakar kedua $=\frac{29}{30} \times 100 \%=96,67 \%$

TABEL X. Perbandingan Hasil Pengujian Pakar Ketiga DENGAN SISTEM

\begin{tabular}{|c|l|l|c|}
\hline $\begin{array}{c}\text { Pengujian } \\
\text { ke - }\end{array}$ & $\begin{array}{l}\text { Hasil Diagnosis } \\
\text { Pakar Ketiga }\end{array}$ & Hasil Diagnosis Sistem & Ket \\
\hline 1 & CRD & CRD 100.0\% & Valid \\
\hline 2 & Marek Disease & Marek Disease 100.0\% & Valid \\
\hline 3 & Colibacillosis & Colibacillosis 97.8\% & Valid \\
\hline 4 & Kolera & Kolera 100.0\% & Valid \\
\hline 5 & CRD) & CRD 100.0\% & Valid \\
\hline 6 & Colibacillosis & Colibacillosis 97.8\% & Valid \\
\hline 7 & $\begin{array}{l}\text { SNOT atau } \\
\text { Coryza }\end{array}$ & $\begin{array}{l}\text { SNOT atau Coryza } \\
100.0 \%\end{array}$ & Valid \\
\hline 8 & $\begin{array}{l}\text { SNOT atau } \\
\text { Coryza }\end{array}$ & $\begin{array}{l}\text { SNOT atau Coryza } \\
100.0 \%\end{array}$ & Valid \\
\hline 9 & CRD & CRD 100.0\% & Valid \\
\hline 10 & CRD & CRD 100.0\% & Valid \\
\hline 11 & ND atau Tetelo & ND atau Tetelo 100.0\% & Valid \\
\hline 12 & $\begin{array}{l}\text { SNOT atau } \\
\text { Coryza }\end{array}$ & $\begin{array}{l}\text { SNOT atau Coryza } \\
99.95 \%\end{array}$ & Valid \\
\hline 13 & Marek Disease & Marek Disease 100.0\% & Valid \\
\hline 14 & Marek Disease & Marek Disease 100.0\% & Valid \\
\hline 15 & Marek Disease & Marek Disease 100.0\% & Valid \\
\hline 16 & $\begin{array}{l}\text { IBD atau } \\
\text { Gumboro }\end{array}$ & $\begin{array}{l}\text { IBD atau Gumboro } \\
93.82 \%\end{array}$ & Valid \\
\hline 17 & $\begin{array}{l}\text { IBD atau } \\
\text { Gumboro }\end{array}$ & $\begin{array}{l}\text { IBD atau Gumboro } \\
86.21 \%\end{array}$ & Valid \\
\hline 18 & $\begin{array}{l}\text { Berak Kapur } \\
\text { Pullorum })\end{array}$ & $\begin{array}{l}\text { IBD atau Gumboro } \\
81.02 \%\end{array}$ & Invalid \\
\hline
\end{tabular}




\begin{tabular}{|c|l|lll|c|}
\hline 19 & $\begin{array}{l}\text { AI atau Flu } \\
\text { Burung }\end{array}$ & $\begin{array}{l}\text { AI atau Flu Burung } \\
100.0 \%\end{array}$ & Valid \\
\hline 20 & ND atau Tetelo & $\begin{array}{l}\text { AI atau Flu Burung } \\
100.0 \%\end{array}$ & Invalid \\
\hline 21 & $\begin{array}{l}\text { AI atau Flu } \\
\text { Burung }\end{array}$ & $\begin{array}{l}\text { AI atau Flu Burung } \\
100.0 \%\end{array}$ & Valid \\
\hline 22 & $\begin{array}{l}\text { SNOT atau } \\
\text { Coryza }\end{array}$ & $\begin{array}{l}\text { SNOT atau Coryza } \\
100.0 \%\end{array}$ & Valid \\
\hline 23 & $\begin{array}{l}\text { SNOT atau } \\
\text { Coryza }\end{array}$ & $\begin{array}{l}\text { SNOT atau Coryza } \\
99.99 \%\end{array}$ & Valid \\
\hline 24 & ND atau Tetelo & ND atau Tetelo 100.0\% & Valid \\
\hline 25 & ND atau Tetelo & ND atau Tetelo 100.0\% & Valid \\
\hline 26 & ND atau Tetelo & ND atau Tetelo 100.0\% & Valid \\
\hline 27 & ND atau Tetelo & ND atau Tetelo 100.0\% & Valid \\
\hline 28 & $\begin{array}{l}\text { AI atau Flu } \\
\text { Burung }\end{array}$ & $\begin{array}{l}\text { AI atau Flu Burung } \\
100.0 \%\end{array}$ & Valid \\
\hline 29 & $\begin{array}{l}\text { AI atau Flu } \\
\text { Burung }\end{array}$ & $\begin{array}{l}\text { AI atau Flu Burung } \\
100.0 \%\end{array}$ & Valid \\
\hline 30 & Marek Disease & \multicolumn{2}{l}{ Marek Disease 100.0\% } & Valid \\
\hline
\end{tabular}

Berdasarkan hasil pengujian antara pakar ketiaga dan sistem didapatkan 28 kasus yang sesuai dan 2 kasus yang tidak sesuai pada kasus ke-18 dan ke-20. Selanjutnya dihitung hasil tangkat kesesuaian sistem dengan contoh kasus Tabel $\mathrm{X}$ yaitu sebagai berikut :

Nilai kesesuaian pakar ketiga $=\frac{28}{30} \times 100 \%=93,33 \%$

Dari 30 contoh kasus yang diberikan pada pengujian akurasi yang dilakukan oleh 3 orang pakar, didapatkan kesimpulan bahwa dari 10 penyakit umum yang diderita ayam terdapat 2 jenis penyakit yang tidak terdapat pada contoh kasus yaitu Infectious Bronchitis (IB) dan kolera, selain itu terdapat beberapa kasus penyakit yang yang tidak sesuai hasil antara diagnosis pakar dengan hasil diagnosis program yang dijabarkan seperti pada Tabel XI.

TABEL XI. Pengujian AKURAsi Masing-Masing Penyakit

\begin{tabular}{|c|c|c|}
\hline No. & Nama Penyakit & Ket \\
\hline 1. & $\begin{array}{l}\text { Newcastle Disease (ND) } \\
\text { atau Tetelo }\end{array}$ & Valid \\
\hline 2. & $\begin{array}{l}\text { Avian Influenza (AI) atau } \\
\text { Flu Burung }\end{array}$ & $\begin{array}{c}\text { Tidak valid pada kasus } 20 \\
\text { oleh pakar ketiga }\end{array}$ \\
\hline 3. & $\begin{array}{l}\text { Infectious Bursal Disease } \\
\text { (IBD) atau Gumboro }\end{array}$ & $\begin{array}{c}\text { Tidak valid pada kasus } 17 \\
\text { oleh pakar } 2 \text { dan Tidak valid } \\
\text { pada kasus } 18 \text { oleh pakar } 3\end{array}$ \\
\hline 4. & Marek Disease & $\begin{array}{c}\text { Tidak valid pada kasus } 2 \text { dan } \\
30 \text { oleh pakar } 1\end{array}$ \\
\hline 5. & Infectious Bronchitis (IB) & - \\
\hline 6. & Kolera & - \\
\hline 7. & Berak Kapur (Pullorum) & Valid \\
\hline 8. & $\begin{array}{l}\text { Cronic Respiratory } \\
\text { Disease (CRD) }\end{array}$ & Valid \\
\hline 9. & Colibacillosis & $\begin{array}{c}\text { Tidak valid pada kasus } 3 \text { dan } \\
6 \text { oleh pakar } 1\end{array}$ \\
\hline 10. & SNOT atau Coryza & Valid \\
\hline
\end{tabular}

Selanjutnya dihitung nilai rata-rata persentase dari ketiga hasil perbandingan antara pakar dan sistem yaitu sebagai berikut :

Nilai rata-rata kesesuaian sistem $=\frac{86,67 \%+96,67 \%+93,33 \%}{3}$

$$
=92,22 \%
$$

Namun apabila diasumsikan hasil pengujian diagnosis oleh pakar 1 pada kasus ke-30 termasuk valid karena merupakan himpunan bagian dari diagnosis penyakit yang diberikan pakar, maka hasil tingkat kesesuaian pada contoh kasus Tabel VIII yaitu sebagai berikut :

Nilai rata-rata kesesuaian sistem $=\frac{90 \%+96,67 \%+93,33 \%}{3}$

$$
=93.33 \%
$$

Sehingga dapat diketahui kesesuaian atau persentase akurasi dari pengujian yang dilakukan antara pakar dan sistem pakar diagnosis penyakit pada ayam dengan menggunakan metode Dempster Shafer yaitu sebesar $92,22 \%$ dan hasil ketidaksesuaian sistem sebesar $7.78 \%$. Jika hasil diagnosis sistem diasumsikan valid karena merupakan himpunan bagian dari diagnosis pakar maka persentase akurasi sistem diperoleh yaitu sebesar $93.33 \%$ dan hasil ketidaksesuaian sistem sebesar 6.67\%. Hasil pengujian yang tidak sesuai disebabkan karena adanya kemiripan beberapa gejala yang dialami ayam yang menyebabkan perbedaan hasil antara diagnosis oleh pakar dan diagnosis oleh sistem. Selain kemiripan gejala perbedaan pengetahuan yang didasari dari data nilai bobot kepercayaan (belief) yang diberikan oleh masing-masing pakar serta perbedaan pengalaman yang dimiliki menjadikan hasil pengujian dan diagnosis pakar berbedabeda dan terdapat ketidaksesuaian antara hasil diagnosis pakar dan hasil diagnosis sistem.

\section{KESIMPULAN DAN SARAN}

\section{A. Kesimpulan}

Kesimpulan yang didapatkan berdasarkan pengujian antara lain :

1. Hasil pengujian akurasi pada 30 contoh kasus yang telah dilakukan menghasilkan kesesuaian tingkat akurasi sebesar 92,22\% dan hasil ketidaksesuaian sistem sebesar $7.78 \%$. Jika hasil diagnosis sistem diasumsikan valid karena merupakan himpunan bagian dari diagnosis pakar maka persentase akurasi sistem diperoleh yaitu sebesar $93.33 \%$ dan hasil ketidaksesuaian sistem sebesar $6.67 \%$.

2. Hasil pengujian kuisioner yang dilakukan oleh responden yang tidak mengerti sistem mendapatkan hasil rentang nilai MOS sebesar 4.93 dari skala 5 dan hasil pengujian kuisioner yang dilakukan oleh responden yang mengerti tentang sistem yaitu sebesar 4.27 dari skala 5, dengan demikian sistem pakar yang dibangun sudah baik dan layak untuk digunakan.

\section{B. Saran}

Beberapa hal yang diperluan untuk pengembangan aplikasi sistem pakar ini agar lebih baik, yaitu sebagai berikut :

1. Sistem pakar untuk mendiagnosis penyakit ayam dapat dikembangkan dengan menggunakan metode yang berbeda sehingga dapat dilihat perbandingan metode yang lebih baik dalam mendiagnosis penyakit pada ayam.

2. Untuk pengembangan sistem pakar selanjutnya dapat ditambahkan fitur-fitur lain seperti pengelolaan data gejala penyakit yang diderita dapat ditambahkan secara manual oleh pengguna, fitur upload foto hewan yang terkena penyakit dan fitur lainnya yang dapat 
membangun sistem menjadi lebih baik. Serta diharapkan dapat dilakukan pengembangan dengan client server sehingga data hasil diagnosis dapat disinkronisasi untuk menghasilkan pembelajaran sistem.

3. Pada penelitian berikutnya dapat dilakukan pembagian antara gejala penyakit yang umum diderita ayam dengan yang khusus sehingga dapat meminimalisir hasil diagnosis penyakit yang berbeda akibat adanya kemiripan gejala.

\section{DAFTAR PUSTAKA}

[1] G. S. Kuncoro, Mulyati, and P. Harsani, "Sistem Pakar Untuk Mendiagnosis Penyakit pada Ayam dengan Metode Fuzzy Tsukamoto," Universitas Pakuan.

[2] Badan Pusat Statistik, "Populasi Ayam Ras Pedaging menurut Provinsi, 2009-2018," Badan Pusat Statistik, $2019 . \quad$ [Online]. Available: https://www.bps.go.id/dynamictable/2015/12/18/1034/pop ulasi-ayam-ras-pedaging-menurut-provinsi-20092018.html. [Accessed: 24-Jan-2019].

[3] Badan Pusat Statistik, "Populasi Ayam Ras Petelur menurut Provinsi, 2009-2018," Badan Pusat Statistik, $2019 . \quad$ [Online]. Available: https://www.bps.go.id/dynamictable/2015/12/18/1031/pop ulasi-ayam-ras-petelur-menurut-provinsi-2009-2018.html. [Accessed: 24-Jan-2019].

[4] Badan Pusat Statistik, "Populasi Ayam Buras menurut Provinsi, 2009-2018," Badan Pusat Statistik, 2019. [Online].

Available: https://www.bps.go.id/dynamictable/2015/12/18/1030/pop ulasi-ayam-buras-menurut-provinsi-2009-2018.html. [Accessed: 24-Jan-2019].

[5] Ir. H. S. Muharyadi, "Populasi Ternak Kabupaten Lombok Timur Tahun 2017,” Kabupaten Lombok Timur, 2017.

[6] S. A. Sitompul, O. Sjofjan, and I. H. Djunaidi, "Pengaruh Beberapa Jenis Pakan Komersial terhadap Kinerja Produksi Kuantitatif dan Kualitatif Ayam Pedaging," Bul. Peternak., vol. 40, no. 3, p. 187, 2016.

[7] A. Winarto, "Sistem Pakar Diagnosis Penyakit pada Ayam Broiler dengan Menggunakan Decision Tree," Universitas Muhammadiyah Ponorogo, 2015.

[8] Drh. M. Ahsan, "Jumlah Puskeswan dan Dokter Hewan Kabupaten Lombok Timur,” 2019.
[9] Santo and Ali mulyono, "Penerapan Metode Demster Shafer Pada Sistem Pakar Diagnosis Penyakit Ayam Broiler Menggunakan Vb.Net 2008 Di Prima Adistwa Farm Cilacap," J. Inform. SIMANTIK, vol. 2, no. September, pp. 18-24, 2017.

[10] R. Hamidi, H. Anra, and H. S. Pratiwi, "Analisis Perbandingan Sistem Pakar dengan Metode Certainty Factor dan Metode Dempster Shafer pada Penyakit Kelinci," J. Sist. dan Teknol. Inf., vol. 1, no. 2, 2017.

[11] E. Setyarini, D. Putra, and A. Purnawan, "The Analysis of Comparison of Expert System of Diagnosing Dog Disease by Certainty Factor Method and Dempster-Shafer Method," Int. J. Comput. Sci. Issues, vol. 10, no. 1, pp. 576-584, 2013.

[12] L. K. Wardhani and R. Kurniawan, "Analisis Perbandingan Metode Bayesian Network dan Dempster-Shafer Pada Sistem Pakar Diagnosis Penyakit Mata," Jurusan Teknik Informatika Universitas Islam Negeri Sultan Syarif Kasim Riau, 2012.

[13] A. Prasetyo, "Sistem Pakar Diagnosis Penyakit Sapi Menggunakan Metode Dempster Shafer Berbasis Web," Universitas Lampung, 2018.

[14] K. S. Permana, "Ketika Pengguna Internet dan Smartphone Terus Meningkat, Android Dominasi Pasar Indonesia dan Dunia," TribunJabar.id, 2019. [Online]. Available: http://jabar.tribunnews.com/2019/01/24/ketika-penggunainternet-dan-smartphone-terus-meningkat-androiddominasi-pasar-indonesia-dan-dunia. [Accessed: 28-Apr2019].

[15] P. P. Abdullah, "Sistem Pakar Untuk Mendiagnosis Penyakit pada Ayam dengan Metode Certainty Factor Berbasis Android," Universitas Lampung, 2016.

[16] S. Maulana, E. T. Tosida, and L. Karlitasari, "Sistem Diagnosis Penyakit Bakteri Ayam Ternak Menggunakan Metode Dempster Shafer," Universitas Pakuan.

[17] G. P. A. S. P. Wibawa, "Sistem Pakar Diagnosis Penyakit Ayam Broiler dengan Metode Dempster Shafer," Sekolah Tingggi Manajemen Informatika dan Komputer AKAKOM Yogyakarta, 2019.

[18] D. Hastari and F. Bimantoro, "Sistem Pakar untuk Mendiagnosis Gangguan Mental Anak Menggunakan Metode Dempster Shafer," J-COSINE, vol. 2, no. 2, 2018.

[19] D. P. Kurniawati, "Implementasi Metode Dempster Shafer Pada Sistem Pakar Untuk Diagnosis Jenis-jenis Penyakit Diabetes Melitus," Universitas Dian Nuswantoro Semarang, 2014 